NBER WORKING PAPER SERIES

\title{
NEW EVIDENCE ABOUT BROWN V. BOARD OF EDUCATION: THE COMPLEX EFFECTS OF SCHOOL RACIAL COMPOSITION ON ACHIEVEMENT
}

\author{
Eric A. Hanushek \\ John F. Kain \\ Steven G. Rivkin \\ Working Paper 8741 \\ http://www.nber.org/papers/w8741 \\ NATIONAL BUREAU OF ECONOMIC RESEARCH \\ 1050 Massachusetts Avenue \\ Cambridge, MA 02138 \\ January 2002
}

An earlier version of this paper was presented at the Brookings Conference on Empirics of Social Interactions (January 2000). Our thanks to conference participants, Caroline Hoxby and Jonah Gelbach for helpful comments. Support for this work has been provided by the Spencer Foundation, the Mellon Foundation, the Smith Richardson Foundation, and the Packard Humanities Institute. The views expressed herein are those of the authors and not necessarily those of the National Bureau of Economic Research.

(C) 2002 by Eric A. Hanushek, John F. Kain and Steven G. Rivkin. All rights reserved. Short sections of text, not to exceed two paragraphs, may be quoted without explicit permission provided that full credit, including (C) notice, is given to the source. 
New Evidence about Brown v. Board of Education: The Complex Effects of School Racial Composition on Achievement

Eric A. Hanushek, John F. Kain and Steven G. Rivkin

NBER Working Paper No. 8741

January 2002

JEL No. I2, H4

\begin{abstract}
Uncovering the effects of school racial composition on achievement is difficult, because racial mixing in the schools is not an accident but instead represents a complex mixture of government and family choices. While the goals of the integration of schools legally inspired by Brown v. Board of Education are very broad, here we focus more narrowly on how school racial composition effects scholastic achievement. Our evaluation, made possible by rich panel data on the achievement of Texas students, disentangles racial composition effects from other aspects of school quality and from differences in student abilities and family background. The results show that a higher percentage of Black schoolmates has a strong adverse effect on achievement of Blacks and, moreover, that the effects are highly concentrated in the upper half of the ability distribution. In contrast, racial composition has a noticeably smaller effect on achievement of lower ability blacks, of whites, and of Hispanics - strongly suggesting that the results are not a simple reflection of unmeasured school quality.
\end{abstract}

Eric A. Hanushek

Hoover Institution

Stanford University

Stanford, CA 94305-6010

and NBER

hanushek@stanford.edu
John F. Kain

Green Center for Study of

Science and Society

University of Texas at Dallas

Richardson, TX 75083-0688

jkain@utdallas.edu
Steven G. Rivkin

Department of Economics

Amherst College

Amherst, MA 01002

sgrivkin@amherst.edu 


\title{
New Evidence about Brown v. Board of Education: The Complex Effects of School Racial Composition on Achievement
}

\author{
by Eric A. Hanushek, John F. Kain, and Steven G. Rivkin
}

One of the most explosive policy issues of the twentieth century was school integration. The political debate and conflict touched most areas of the country. Much of the public discussion centered on the proper role of racial desegregation and the best methods for accomplishing its purposes. Despite the lack of policy consensus, there have been substantial changes in enrollment patterns in U.S. public schools. However, close to fifty years after the landmark school desegregation case of Brown v. Board of Education, a surprising amount of uncertainty still exists about the ultimate effects of school desegregation on academic, social, and labor market outcomes for both minority and white students. This study pursues a new approach for isolating the effects of school racial composition on achievement and provides estimates of its importance for the State of Texas.

The ruling in Brown v. Board of Education (1954) held that separate but equal, while not inherently unconstitutional in all areas, was unconstitutional in the case of education because separate could not be equal. ${ }^{1}$ This ruling led to dramatic changes in schools throughout the country, and the history of changes in enrollment patterns both for the nation and for Texas provides an important backdrop for this study. These changes did not take place overnight, and, even 15 years after the initial court ruling, schools remained largely segregated. The decade of the 1970s, however, witnessed a substantial reduction in segregation brought about largely through legal pressure on local school districts (Welch and Light (1987)). But the countervailing trend of the large-scale exodus of whites from many cities and towns clearly dampened the impact of school desegregation on interracial contact.

Texas schools are interesting as an example of the changes that have occurred in many previously segregated systems. They experienced the dual pressures of court-ordered 
desegregation decrees and dramatic demographic shifts resulting from suburbanization, immigration, and rapid overall population growth. The combination of these and other forces leaves today's black public school students in Texas likely to have far more white schoolmates than did their parents or grandparents in the late 1960s.

Despite reductions in segregation and other aspects of school inequality, black students in Texas have achievement noticeably below white students, mirroring that for the nation as a whole. For example, the average mathematics score for black seventh graders is 0.7 standard deviations below that of whites. Further, only 29 percent of blacks score in the top half of the state distribution.

This paper investigates the contribution of school racial composition to the racial and ethnic achievement gap. It makes use of a unique matched panel data set on individual students and schools to identify the impacts of racial composition on academic achievement and to differentiate these from other aspects of school quality that might drive any observed relationship between achievement and school demographic composition. While controls for observable family and school characteristics are used, it is the ability to control for an array of fixed effects that permits the clearest identification of the effect of racial composition. Ultimately, we identify these effects by differences in the pattern of racial composition for successive cohorts of students in a given school as they age.

To set the stage, it is useful to consider the simple correlations between achievement and percentage of schoolmates who are black separately by ethnicity for Texas public schools. Table 1 shows that percentage black is largely uncorrelated with achievement for whites and Hispanics in all grades. In contrast, the correlation becomes much more negative for blacks as they progress through grades four to seven. Though these simple cross-sectional correlations do not control for any confounding factors, their pattern suggests that peer percentage black may affect blacks much more than other ethnic groups, and that the effects appear to cumulate and increase in magnitude

${ }^{1}$ Brown v. Board of Education, 347 U.S. 483 (1954). 
as students progress through junior high. By themselves, however, these results give little indication of what might lie behind the patterns - teacher quality differences, peer effects, family and student selection effects, or other related factors.

Our basic estimation of elementary school achievement growth confirms the simple results: achievement for black students is negatively related to the black enrollment share. But the full analysis provides a more complex picture - the adverse effects of racial composition are concentrated on higher ability blacks. In contrast, racial and ethnic composition has considerably less influence on the achievement gains of whites or Hispanics, indicating that racial composition is not serving as a proxy for general school or teacher quality. This peer effect for blacks is also not driven by racial differences in average achievement or SES. Nor is it a minority effect, because concentrations of other minority groups, notably Hispanics, do not significantly affect black students.

This analysis is limited to investigation of pure racial composition effects and does not investigate other differences in school quality that might be correlated with race. For a variety of reasons, we suspect that other school disadvantages also increase with more racial concentration, and these would be additive to the peer influences uncovered here.

\section{School and District Enrollment Patterns}

The evolution of school enrollment patterns provides important information on the determinants of school racial composition and the potential biases that must be addressed in trying to isolate the causal effect of school racial composition on achievement. Racial separation in public schools today is primarily attributable to residential segregation across jurisdictions. Rivkin (1994) shows that in 1988, even if all U.S. school districts had been perfectly integrated (each school having the district share of all demographic groups), housing patterns would have led to a schooling system in which large numbers of blacks would have few white schoolmates. The time pattern of integration of Texas public schools is quite similar to those of all southern 
states grouped together as well as the U.S. as a whole, but, as described below, the distribution of black students by percent black in their schools is more even than in many other southern and northern states.

Table 2 shows the demographic composition of Texas public schools. ${ }^{2}$ Between 1968 and 1998 the relative decline in white enrollment was roughly offset by increases in Hispanic enrollment, while the black enrollment share declined only slightly. White enrollment fell from 64 percent to 45 percent of the total during the thirty-year period, while Hispanic enrollment increased from 19 percent in 1968 to 38 percent in $1998 .^{3}$ In sum, Texas public schools experienced substantial changes in demographic composition. ${ }^{4}$

Despite the pronounced decline in the overall share of white enrollment, the average percentage of blacks' schoolmates who were white (exposure index) increased by roughly 50 percent between 1968 and 1980, rising from 24 to 35 percent (Table 3). This increase was driven primarily by the expansion of school desegregation efforts across the state. Since 1980, however, exposure has fallen, reflecting the decline in the white share of enrollment and lack of new desegregation programs. The rise in exposure during the 1980s and subsequent decline is similar to the pattern observed for the United States as a whole.

\footnotetext{
${ }^{2}$ The Texas data on students (discussed below) along with data from the Office of Civil Rights (OCR) BiAnnual Survey of Public Schools for 1968, 1980, and 1992 are used in the description of school and district enrollment patterns. Adding the OCR data permits us to document enrollment patterns over the thirty-year period from 1968 to 1998. The data provide school enrollment counts for American Indians, Asians, blacks, Hispanics, and whites as well as weights that can be used to produce projections for the state as a whole. The OCR data contain a sample of districts for each state. Sixty-five Texas districts are sampled in all surveys, and we compute separate enrollment statistics for each of these districts. Our analysis eliminates one sampled district that was reconstituted over the time period. Importantly, because the OCR surveys only a portion of the public schools in Texas, the data must be weighted by the inverse probability of selection into the sample to generate statewide projections. Not surprisingly the different samples (OCR and Texas administrative data) produce slightly different segregation and enrollment statistics for 1992, the year the two data sets overlap. However, the aggregate differences are minor (as shown below), and the statistics for the individual school districts are virtually identical.

3 Differences between the PEIMS (Public Education Information Management System) from the State of Texas and the OCR data for 1992 suggest that the OCR either undercounted or undersampled Hispanics, which would lead to an overstatement of the decline in the white share of enrollment.

${ }^{4}$ Despite the dramatic shifts in public school demographic composition, the rate of attendance at private schools in Texas is below that for the nation - 6 versus 11 percent in 1997 - and was virtually unchanged between 1980 and 1997. Thus it accounted for little of the changes experienced by the public schools.
} 
The reduction of segregation that led to increased exposure during the 1980s is captured quite well by the school dissimilarity index (second row of Table 3), measured as the percentage of whites (or blacks) who would have to change schools in order for the white and black enrollment shares to be identical in all schools. It ranges from 0 (complete integration) to 100 (complete segregation). The Texas index declines from 74 percent in 1968 to 61 percent in 1980, but only slightly more in the subsequent period. Thus while there was a substantial reduction in segregation during the 1970s, there was little additional progress in the 1980s and 1990s.

Importantly, school segregation is determined by both the distribution of families among districts (residential choices) and district attendance patterns. ${ }^{5}$ The degree to which ethnic groups concentrate in different districts limits the extent to which school district policies can reduce overall school segregation. Comparisons of residential segregation by district (third row of Table 3) and school segregation reveal a convergence over time, indicating that the current distribution of school racial composition cannot be altered much without moving students across district lines - a policy that is difficult to justify legally and something only rarely contemplated in judicial or legislative actions.

Texas does, nonetheless, differ from many other states in the history and pattern of its development. The presence of significant numbers of blacks historically engaged in farm pursuits and living in farm communities that were engulfed by metropolitan growth meant that a fair number of high-income suburban communities and their associated school districts had, with the eventual elimination of de jure school segregation, non-trivial numbers of black students attending these schools. It also led to the relatively dispersed pattern of attendance by blacks

\footnotetext{
${ }^{5}$ It is not possible to quantify the extent to which this increase in residential segregation was a direct response to district desegregation efforts. Welch and Light (1987) provide overwhelming evidence of white flight in response to the implementation of desegregation plans, though Rivkin (1994) shows that between 1968 and 1988 the trend toward white exiting of central cities occurred regardless of whether segregation plans had been adopted. Recent data (1987-1996) show continued of white movement away from districts schools with higher white exposure to nonwhites (Clotfelter (2001). Moreover, Massey and Denton (1993) document that the pattern of suburbanization of blacks and whites carried many of the prior segregated housing arrangements to the suburbs.
} 
shown in Figure 1, where half of the black students attend schools in which one-third or less of student body is black. This pattern is an important source of variation that is not present in many other parts of the country and that contributes to the analyses that follow.

The overall distributional data show the patterns of racial exposure that have emerged in the schools, and they underscore the potential impediments for any changes, at least through the existing array of school based policies. More importantly for our purposes, they make abundantly clear that housing patterns and school district attendance policies combine to determine the distribution of students into schools. Additionally, one conclusion, fitting into the national model of change, is that any given racial composition can come about in very different ways. Because family and community differences are closely related to each of these factors, they clearly complicate the identification of an exogenous source of variation in school racial composition and make analysis of the effects of racial composition on student performance very difficult.

\section{Prior research on racial peer effects}

The academic literature includes a wide variety of analyses and perspectives on race and achievement. The only social science evidence of harm from school segregation cited by the U.S. Supreme Court in Brown involved psychological studies of black children that related low selfesteem to segregated schools. ${ }^{6}$ Many of the early (post-Brown) analyses then concentrated on the effects of desegregation on achievement, self-esteem, and racial attitudes. These studies, which focused on short run effects of purposefully moving students to less segregated schools, consider a variety of student outcomes and yield mixed effects of desegregation (Crain and Mahard (1978), Cook (1984), Armor (1995)). Many desegregation plans ordered by courts were accompanied by conflict and resistance so that most short run investigations of the impact of integration on achievement are contaminated by factors related to the desegregation process.

\footnotetext{
${ }^{6}$ Footnote 11 of Brown refers to the doll studies of Kenneth and Mamie Clark (Clark and Clark (1939)) that found that blacks in the segregated South tended to identify with white dolls and not black dolls.
} 
Perhaps more important, however, these studies are plagued by methodological problems largely related to sample selection issues but also including the heterogeneity of desegregation circumstances - making it difficult to assess the general impact of desegregation efforts.

Another segment of this literature focused on not so much on student outcomes but on the impact of desegregation efforts on the subsequent racial composition of schools. Beginning with analysis of "white flight" in the face of court ordered desegregation by Coleman, Kelley, and Moore (1975), much of the analytical focus shifted to outcomes defined in terms of racial contact (Welch and Light (1987)). ${ }^{7}$

Finally, a related but distinct strand of research focuses on whether peer racial composition, as opposed to desegregation actions, affects achievement for blacks as well as for other demographic groups. This research does not consider the underlying determinants of racial composition but rather concentrates on its link with student outcomes. The landmark legislatively mandated civil rights report on Equality of Educational Opportunity (Coleman et al. (1966)) and its offshoots (U.S. Commission on Civil Rights (1967)) provided empirical evidence that racial isolation harms academic achievement, ${ }^{8}$ although this was soon questioned (Armor (1972)). Subsequent work by Crain (1970), Boozer, Krueger, and Wolkon (1992), Grogger (1996), and Hoxby (2000) finds that school racial composition affected academic, social, or economic outcomes. Hanushek (1972) finds that higher concentrations of blacks hurts both whites and blacks, but - related to the estimation developed below - is concerned that the racial composition of the school may simply be a proxy for heterogeneity in school quality and other omitted factors. Kain and O'Brien (2000), upon which this paper builds, find that blacks benefit a great deal from moving to the suburban schools that are more racially mixed. In contrast, Rivkin (2000) finds no

\footnotetext{
7 A related line of inquiry investigates racial composition and private schools (e.g., Clotfelter (1976)). Whether or not private schools tend to be more segregated than public schools has been the subject of considerable policy debate since Coleman, Hoffer, and Kilgore (1982). These issues are, however, beyond the scope of this analysis.
} 
evidence that exposure to whites increases academic attainment or earnings for Black men or women in the high school class of 1982, and Cook and Evans (2000) indicate that little of the black-white difference in National Assessment of Educational Progress scores can be attributed to racial concentration. Finally, a more recent comprehensive review finds the evidence on achievement and psychological differences is very mixed Schofield (1995)).

The contrasting findings and lack of consensus concerning the importance of school racial composition likely emanate in large part from the difficulty of isolating the causal impact of peer characteristics. As Manski (1993), Moffitt (2001), and Brock and Durlauf (forthcoming) point out, the empirical analysis of peer influences has been inhibited by both conceptual and data problems - problems that raise serious questions about interpretation of the existing studies, even those that use more sophisticated econometric techniques including instrumental variables.

While much of the theoretical literature emphasizes the details of current interactions among students, these issues, as we develop below, appear much less important than more standard ones of unobserved or mismeasured variables. For example, in the studies of school racial composition effects, neither Crain (1970) nor Boozer, Krueger, and Wolkon (1992) provide many statistical controls for differences in socio-economic background or prior academic preparation. ${ }^{9}$ Unlike the other papers, Grogger (1996) uses a longitudinal data set that contains information on family background and achievement measures, though it is unlikely that this small number of variables would account for all factors that are related to both outcomes and the choice of schools. The inclusion of private school students in the analysis further increases the likelihood that the school racial composition coefficients are biased upward. Rivkin (2000) uses school

\footnotetext{
${ }^{8}$ The Coleman Report data, collected in 1965, largely reflect the legal and behavioral equilibrium before court ordered desegregation efforts, because most desegregation plans were instituted in subsequent periods (Welch and Light (1987)).

${ }^{9}$ Boozer, Krueger, and Wolkon (1992) use two stage least squares in an attempt to control for nonrandom selection into integrated schools. The 2SLS estimates are much less precise than the OLS estimates; moreover, the instrumenting strategy uses variation across time and state in school racial composition, and such variation may be correlated with other determinants of earnings.
} 
district aggregate measures of exposure to whites in order to overcome the nonrandomness of both neighborhood location within districts and attendance in non-neighborhood schools; nevertheless, unobserved differences among districts may contaminate the estimates. In general, because families with greater resources or a greater commitment to schooling tend to attend schools with lower black enrollment, the racial composition effects are easily confounded with common but unobserved elements of families, schools, and neighborhoods. ${ }^{10}$

In an innovative effort to address these issues, Hoxby (2000) relates average school achievement by cohort to detrended school racial composition and achievement differences for adjacent cohorts to identify the causal effect of peer group composition. One clear complication, however, is that the high rate of school transfers, particularly by nonwhite students, appears far more important than biological or birth rate differences in accounting for variation between cohorts - implying that attention must be given to school and family factors that are related to changes in racial composition. ${ }^{11}$ A second and related concern is the potential importance of unobserved differences in teacher and school quality. These issues are central to our development below. ${ }^{12}$

The generally mixed findings and methodological differences of prior analyses, highlighted in Schofield (1995), motivate our modeling approach. Specifically, inadequate attention to conceptual and analytical difficulties have interacted with serious data limitations to produce inconclusive findings on one of the most significant social policies of the past half century.

\footnotetext{
${ }^{10}$ See Tiebout (1956) for a discussion of the link between family preferences and neighborhood location.

${ }^{11}$ See Hanushek, Kain, and Rivkin (2001) for information on school mobility in Texas, the site of Hoxby's investigation.

12 One final complication arises in her use of average achievement differences across ethnic groups to infer whether the racial composition effects are driven by achievement differences. Such differences are endogenous and are likely result from a variety of unmeasured factors including differences in teacher quality.
} 


\section{Methodology}

At the outset, it is important to be clear about the relationships that are being estimated and about the interpretation of any empirical results. We begin with an explicit statement of how peers enter into the determination of achievement, and use this to motivate our empirical strategy. ${ }^{13}$ The approach focuses attention on identification of the peer parameters of interest and controls for the most obvious sources of potential contamination through the use of student, school-by-grade, and district-by-year fixed effects in achievement gain and the inclusion of a number of time varying student and school characteristics. The remaining variation in school racial and peer composition provides a compelling source of identification of the relationship between achievement and peer demographic composition, though it does not identify the underlying pathways through which peers affect one another.

\section{Empirical Model of Achievement with Peer Influences}

While well-recognized even if not incorporated in many empirical specifications, today's achievement is influenced not just by current family, school, and peer interactions but also by those of the past that establish the base for any current learning. This fundamental relationship is captured by Equation (1) that describes achievement (A) for student i in grade G, in school s, (eq. 1)

$$
\mathrm{A}_{i G s}=\underbrace{X_{i G s} \beta_{G}+S_{G s} \delta_{G}+\bar{P}_{(-i) G s} \lambda_{G}}_{\text {current inputs }}+\underbrace{\sum_{g=1}^{G-1} X_{i g s} \beta_{g}+\sum_{g=1}^{G-1} S_{g s} \delta_{g}+\sum_{g=1}^{G-1} \bar{P}_{(-i) g s} \lambda_{g}}_{\text {cumulative past inputs }}+\sum_{g=1}^{G} e_{i g s}
$$

where $\bar{P}$ measures peer behavior and $\mathrm{X}$ and $\mathrm{S}$ are vectors of relevant family background and school inputs, respectively, and the subscript (-i) indicates that peer measures omit attributes of

\footnotetext{
${ }^{13}$ The model builds on our prior analysis of peer effects in Hanushek et al. (forthcoming).
} 
student i. Because it is useful for developing the estimation issues, this representation separates current and past influences. ${ }^{14}$

Much of the existing empirical work on the influences of peers - relying on just contemporaneous data on families, schools, and peers - concentrates on the direct investigation of how aggregate characteristics of the school such as racial composition or peer average ability influence current achievement. Yet in the absence of random assignment to schools, current peer group composition is almost certainly correlated with past composition and other current and past determinants of achievement through the choice of neighborhood and school. Because it is quite difficult to control for all relevant factors, estimates of Equation 1 using ordinary least squares or other single equation methods will tend under very general conditions to overstate the influence of peers.

Our approach to the general problem of estimating achievement relationships begins by taking the first difference of equation (1). Specifically, if $\mathrm{A}_{\mathrm{G}-1}$ is determined by the same basic relationship as $A_{G}, A_{G-1}$ includes all of the inputs through grade $\mathrm{G}-1$. The specification of achievement in terms of growth, more commonly referred to as a value-added specification, reduces the data requirements to the inputs relevant for grade $G$, since all of the historical influences on the current achievement level drop out. Equation (2) describes the value added specification:

(eq. 2)

$$
\Delta A_{i G s}^{c}=X_{i G s}^{c} \beta+S_{G s}^{c} \delta+\bar{P}_{(-i) G s}^{c} \lambda+v_{i G s}^{c}
$$

where $\Delta A_{i G s}^{c}$ is the achievement gain (difference between current grade and previous grade test scores) for student $\mathrm{i}$ in grade $\mathrm{G}$ in school s in cohort c. ${ }^{15}$ Student achievement growth is related to

\footnotetext{
${ }^{14}$ Presentation of achievement solely in terms of school experiences, ignoring preschool experiences, is
} 
the contemporaneous inputs (which are the flows of these factors over the observed time period), and the generic problems of omitted historical variables are circumvented. ${ }^{16}$ Such estimation, which requires data with just two observations on each student, has been considered state of the art in estimation of achievement models (Hanushek (1986)).

This specification does not, however, circumvent problems that arise from omitted or mismeasured contemporaneous factors. For three reasons, this issue is particularly important in the context of estimating peer influences on achievement growth. First, the accumulated research on achievement determination has vividly demonstrated the difficulties in adequately characterizing not only schooling inputs but also individual ability and family inputs (see Hanushek (1997, 1986), Rivkin, Hanushek, and Kain (2001)). Second, systematic decisions about neighborhood and school choice by parents induce a well-documented correlation among family characteristics such as income, education, and race. Third, because many parents have better information about schools and other families in the neighborhood than the econometrician has, poorly measured school quality elements will be correlated with the aggregate measures of families such as average test score, income or racial composition usually included as peer group characteristics. These factors combine to elevate the importance of model specification in the case of peer estimation, because these omitted factors by themselves could make peers appear important even in the case when there is no achievement influence of peers (cf. Moffitt (2001), Hanushek et al. (forthcoming)).

Our primary strategy for dealing with these general specification issues relies on purging the error term of the systematic differences in families and schools that are the primary sources

\footnotetext{
done solely for expositional ease. Given our estimation strategy, it has no effect on the results.

${ }^{15}$ An alternative estimation approach is to add a measure of prior achievement to the right hand side. This approach does not constrain the parameter on prior achievement to be one but does add other complications with estimation (see Hanushek (1979), Rivkin, Hanushek, and Kain (2001)). The identification of separate cohorts facilitates development of the subsequent estimation strategy.

16 This formulation assumes that current inputs do not affect the rate of learning in future periods. Violations of this assumption will bias downward the estimated effects of specific variables on achievement.
} 
of bias. From the starting point of equation (2), equation (3) decomposes the error, $v$, into a series of components highlighting those factors most likely to contaminate the peer estimates. (eq. 3)

$$
v_{i G s}^{c}=\omega_{i}+\omega_{s}+\omega_{G s}+\tau_{G}^{c}+\theta_{G s}^{c}+\varepsilon_{i G s}^{c}
$$

The first three terms capture time invariant individual $\left(\omega_{\mathrm{i}}\right)$, school $\left(\omega_{\mathrm{s}}\right)$, and school-by-grade effects on achievement $\left(\omega_{\mathrm{Gs}}\right)$; the fourth factor $\left(\tau_{G}^{c}\right)$ captures grade-by-year differences in the testing regime; the fifth component $\left(\theta_{G s}^{c}\right)$ captures school-by-grade effects that vary from cohort to cohort, most notably the quality of teaching; and the final factor $(\varepsilon)$ is a random error capturing individual achievement shocks that vary over time.

Our estimation makes use of stacked panel data for successive cohorts explicitly to remove the first four components of the error term: fixed individual, school, school-by-grade, and grade-by-year effects. The estimation of peer group effects relies therefore on cohort differences in the changes in racial composition as students progress through school, i.e., the estimates are identified by small differences in the within school and grade pattern of percent black, percent Hispanic, and ability (the included peer variables described below) between cohorts. Such differences come from cohort differences in grade-to-grade differences in mobility into and out of the school. The large annual mobility of students, averaging greater than 20 percent per year in the Texas public schools, generates substantial variation in school racial composition even for adjacent cohorts (Hanushek, Kain, and Rivkin (2001)).

Notice how the fixed effects account for the primary systematic but unobserved differences in students and schools. The student fixed effects (in the gains formulation of equation 2) account for all student and family factors that do not vary over the period of achievement observation and that affect the rate of learning - including ability differences, child rearing practices, general material inputs, consistent motivational influences, and parental 
attitudes towards schools and peers. Any fixed differences in schools that are not perfectly correlated with the student fixed effects or included covariates (S and X) - but typically correlated with peer group composition through school and neighborhood choice - are accounted for by school fixed effects. These effects include stable elements of school quality, of teacher quality, and of curriculum. Finally, even systematic within school changes in achievement gains as students age - such as those that result from specific curricular emphasis or from specialized programs of a school or district - can be accounted for through the use of school-by-grade fixed effects.

The importance of the multiple cohorts, which allow estimation of school-by-grade fixed effects, should not be underestimated in the peer context. Consider the possibility that achievement for students in some schools tends to decline at the same time that the black share of enrollment rises. Perhaps nonblack families become more likely to remove their children from the public schools or to move to the suburbs as students age. If only fixed individual and school effects were removed (as is possible with panel data for a single cohort), the negative estimate on proportion black would suggest that increases in proportion black harmed achievement when in fact other factors had introduced a spurious relationship between achievement gain and student racial composition. On the other hand, if fixed student and school-by-grade effects are removed as is possible with data for multiple cohorts, such systematic changes in specific schools cannot drive the results.

The chief residual concern is whether any remaining variation over time in factors affecting achievement is correlated with racial composition patterns across our sample. School district policies and actions are of particular concern because a significant proportion of local policy is made at the district level including hiring practices and pay, teacher and principal assignments to schools, the determination of school attendance boundaries and placement rules, and the like. Moreover, of particular relevance to this work, districts develop policies related to racial composition of schools, desegregation plans, and any legal issues in the area. This range of 
policies and issues potentially affect student achievement directly along with being correlated with student movements into schools and districts - either because they are causally related through parental and district behavior or because they are simply coincidental in timing across districts in the state.

While we believe that these time varying district factors are unlikely to be systematically related to racial composition across the state, we can directly deal with them by adding a further term $\left(\delta_{\mathrm{dy}}\right)$ that captures fixed district-by-year influences on achievement. Thus in the most complete specifications, we directly remove any concurrent district factors that might bias our estimation of the impact of racial composition. ${ }^{17}$

\section{Peer Structure}

To this point the discussion has focused on the special econometric complications of peer estimation but not on specification and interpretation of peer influences themselves. The common conceptual discussion of peers revolves around social interactions in terms of motivations, direct educational inputs, or even the externalities in the classroom through, say, the quality of individual discussion and questions or pure disruptive behavior (cf. Lazear (2001)). Most investigations of peers, however, never observe or measure any attributes of actual behavior but instead include aggregate observable characteristics of the students such as race, income, or ability. This approach, which we also follow, essentially extracts common elements of average behavior. It stops short of taking the analysis to a more fundamental behavioral level that recognizes the heterogeneity of the aggregate racial, income, and ability categories, because little is known or observed about more basic factors. Thus, for example, the initial doll studies that

\footnotetext{
${ }^{17}$ The removal of school-by-year fixed effects would control for all year-to-year variation common across grades, leaving only grade specific deviations to identify the peer group effects. Though this would provide completely unconstrained control for school specific changes over time, this approach is infeasible because a substantial fraction of the schools only contribute a single grade to the analysis (mainly because many districts have students move into a common middle school ). Nonetheless, in the large number of districts
} 
partially motivated the Brown decision considered how children in segregated environments formed notions of racial identity but did not investigate the range of heterogeneity related to family, neighborhood, or school differences in the reactions of black children. As a result, the simple depiction of mean differences in outcomes by race, income, or other factors is best thought of as a reduced form relationship that aggregates underlying behavior across readily identified but crude categories.

Equation (4) follows convention and describes the link between peer behavior and measured peer composition in each year as a simple linear function of classmate aggregates:

(eq. 4)

$$
\bar{P}_{(-i) G s}=B_{(-i) G s} \gamma_{B}+H_{(-i) G s} \gamma_{H}+\Gamma_{(-i) G s} \gamma_{A}+Y_{(-i) G s} \gamma_{Y}+u_{(-i) G s}
$$

where $\mathrm{B}$ is proportion black, $\mathrm{H}$ is proportion Hispanic, $\Gamma$ is peer average ability or cognitive skill, $\mathrm{Y}$ is a measure of peer family income, and $\mathrm{u}$ is an error term that captures all other influences on peer behavior. ${ }^{18}$

The substitution of proportion black, proportion Hispanic, and peer average ability (measured by past peer achievement) in place of peer behavior produces the reduced form specification that forms the basis of our empirical analysis. ${ }^{19}$

(eq. 5)

with a single middle school, district-by-year fixed effects effectively account for unobserved factors common to all grades.

${ }^{18}$ Note that all peer variables omit the individual from the calculations, i.e. they refer to schoolmate and not school simply school characteristics.

19 Preliminary work found that none of the other peer variables were sensitive to the inclusion of the peer income variable (percentage of students eligible for a subsidized lunch). Because this measure of income is noisy and in part dependent on the effectiveness of schools in obtaining information on family income, it is omitted from the analysis. 


$$
\begin{aligned}
\Delta A_{i G s}^{c}= & X_{i G s}^{c} \beta+S_{G s}^{c} \delta+B_{(-i) G s} \gamma_{B}+H_{(-i) G s} \gamma_{H}+\Gamma_{(-i) G s} \gamma_{A} \\
& +\omega_{i}+\omega_{G s}+\tau_{G}^{c}+\delta_{d y}+\left(\theta_{G s}^{c}+\varepsilon_{i G s}^{c}+\mu_{(-i) G s}^{c}\right)
\end{aligned}
$$

In this simple framework the coefficients on the observed peer group characteristics will reveal the link between achievement and these variables but not the underlying relationships between these variables and specific peer behavior (such as disruptions per class period) and between that peer behavior and achievement. Of course the assumption that peer behavioral influences can be adequately compressed into a single dimension $(\mathrm{P})$ is likely to miss much of the complexity and heterogeneity of classroom interactions. Nevertheless, these reduced form coefficients provide the relevant information for policies related to racial composition. Moreover, we are able to explore the possibility that the racial composition effects are nonlinear or that they differ by initial achievement, race or ethnicity. Finally, by alternately including and then excluding the measure of peer average ability we can learn a great deal about the extent to which average achievement differences among race/ethnic groups account for any observed link between racial or ethnic composition and achievement. ${ }^{20}$

\section{Potential Problems}

The validity of the fixed effect estimation strategy hinges upon the assumption that the two remaining time-varying components of the error terms ( $\theta$ and $\varepsilon$ from equation 3$)$ are orthogonal to the peer variables. One significant concern of course is the possibility that changes in racial composition are correlated with other changes in family or school inputs. The severity of this potential problem depends in part on the ability to control for changes in families and

20 The average of peers' achievement two years earlier rather than current achievement captures stable cognitive ability differences but does not include any measures of the contemporaneous innovations in achievement that might reflect interactive behavior. While current peer average achievement provides a better measure of contemporaneous peer ability, its inclusion would raise the essentially insoluble reflection problem described by Manski (1993). The use of past average achievement likely introduces a small amount of measurement error when contemporaneous achievement accurately measures the true influences, but empirically the pattern of changes in the racial composition coefficients is virtually identical 
schools. As noted above, we include a variety of time varying measures for family income, school characteristics, and overall school transfer behavior. Perhaps more important given the controls for student, school-by-grade, and district-by-year fixed effects, the severity also depends upon the speed with which families relocate in response to expected problems in the coming school year. Because residential moving is a costly process that undoubtedly includes some slow adjustment, movement due to parental selectivity of schools is almost certainly much slower than the movement of peer characteristics found in natural year-to-year variations. With the removal of district effects in a very general way for each year, the only concern is idiosyncratic school variations that are, across the sample, correlated with changes in racial composition. Parents may anticipate changes in teacher quality, for example, but such information about individual schools is not generally available before the year begins. Moreover, the assumption that families also react slowly (i.e., not in the current year) to specific variations in teacher quality also seems natural, suggesting that year-to-year changes in teacher quality are unlikely to be systematically linked with changes in peer group composition. ${ }^{21}$

Finally, the time-varying school effect, $\theta$, includes both within school variation in teacher quality and changes that occur over time. The estimation of racial composition effects presumes that $\theta$ is uncorrelated with racial composition across the sample. At the classroom level, this presumption could be violated by explicit classroom placement policies. For example, if higher achieving minority students tended to have more white classmates, estimates derived from variation at the classroom level would confound actual peer effects with unobserved student characteristics. This classroom placement problem is handled, however, by aggregating

regardless of whether lagged or current achievement is used to capture peer achievement differences. See Hanushek et al. (forthcoming) for a detailed discussion of this issue.

${ }^{21}$ Remaining variation in annual teacher quality, while large, is orthogonal to school-by-grade quality differences. The latter almost certainly provide the prime motivation for any family selection of schools, and, particularly when the average family has more than one child, it is unlikely that year-to-year variation in quality in a single grade would induce many families to move. 
classrooms to the grade level. ${ }^{22}$ With that, the racial composition effects are estimated from shifts in composition across grades and across cohorts and the time invariant placement practices by school and grade are removed with the fixed effects. Thus, it is unlikely that purposeful placement patterns would vary with yearly patterns in racial composition across grades in a systematic way that would bias the estimates.

\section{Other Issues and Extensions}

First, much of the conceptual and descriptive discussion of peer influences is vague about the nature of peer group formation, though most analyses simply average across all of the students in a school. ${ }^{23}$ If, however, there is substantial within school segregation by race or ethnicity in terms of social interactions, only characteristics of same race/ethnic peers may be important. In such a case, school wide averages will provide noisy measures of peer average achievement or income that lead to underestimates of the effects of these variables. By alternately including all schoolmates or separating same race/ethnic and other schoolmates in the calculation of peer average achievement, we learn more about the nature of peer group relationships.

Second, the historical patterns of desegregation of schools are quite varied. Since Brown, some districts have gone through traumatic times of involuntary desegregation of schools, while others have moved easily from all white schools to stably integrated schools. Most of the development of court supervised integration plans occurred in the 1960s, 1970s, and early 1980s, before any of our observations of student performance. Therefore two schools with similar racial compositions in the mid 1990s could have arrived at that point in very different ways. For

\footnotetext{
22 This estimator is equivalent to using the grade average as an instrumental variable. While other approaches for dealing with within school placement may conceptually be available, our data do not permit such matching, and we do not pursue any such strategies here. Clotfelter, Ladd, and Vigdor (2002) investigate segregation by district, school, classroom, and academic track for seventh graders in North Carolina. They find significant variations in racial composition of classrooms along with large differences in the probability of new teachers for blacks, but they do not look at its implications for student performance.

${ }^{23}$ See Manski (1993) and Moffitt (2001) on the issues of endogenous peer group formation.
} 
example, for the 62 districts sampled over time by the Office of Civil Rights and having sufficient data for racial exposure calculations, 27 districts showed an increase in white exposure for the average black student of 10 percent or more from 1968 to 1992, while another 15 districts showed a decrease of 10 percent of more over the same period. While we do not have the details of the ways in which these changes occurred - say, by legal action, white flight, or new housing developments - we can investigate whether the path of change influences the social interactions captured by the racial peer effects on achievement.

\section{UTD Texas Schools Data}

The cornerstone of the analysis of racial composition effects on achievement is a unique matched panel data set of school operations constructed by the UTD Texas Schools Project, a project conceived of and directed by John Kain. The data track the universe of three successive cohorts of Texas public elementary students as they progress through school, beginning with students who attended third grade in 1992. For each cohort there are over 200,000 students in over 3,000 public schools. Unlike many data sets that sample only small numbers from each school, these data enable us to create quite accurate measures of peer group characteristics. We use data for grades four through six for one cohort and grades four through seven for two others. The most recent cohort attended $5^{\text {th }}$ grade in 1996 , while the earliest cohort attended $5^{\text {th }}$ grade in 1994. Only black, Hispanic, and white students are included in the analysis though all students are used in the calculations of peer characteristics; the relatively small numbers of Asian and Native American students are excluded in order to simplify the models.

The student data contain a limited number of student, family, and program characteristics including race, ethnicity, gender, and eligibility for a free or reduced price lunch (the measure of economic disadvantage) and Title I services. The panel feature of the data, however, is exploited to account implicitly for a more extensive set of background characteristics by removing time 
invariant individual effects on achievement gains. Importantly, students who switch schools can be followed as long as they remain in a Texas public school.

Beginning in 1993, the Texas Assessment of Academic Skills (TAAS) was administered each spring to eligible students enrolled in grades three through eight. The criteria referenced tests evaluate student mastery of grade-specific subject matter. This paper presents results for mathematics, although the results are qualitatively quite similar for reading. Consistent with the findings of our previous work on Texas, schools appear to exert a much larger impact on math than reading in grades 4 through 7 (see Hanushek, Kain, and Rivkin (forthcoming) and Rivkin, Hanushek, and Kain (2001)). Each math test contains approximately 50 questions. Because the number of questions and average percent right varies across time and grades, we transform all test results into standardized scores with a mean of zero and variance equal to one, which transforms the outcome into a measure of relative position in the achievement distribution. The regression results are robust to a number of transformations including the raw percentage correct. In order to avoid complications associated with classification as limited English proficient (LEP) or disabled, all LEP and special education students are dropped from the direct achievement analysis, although these students are included in the peer calculations.

Importantly, the student database can be linked to information on teachers and schools. The school data contain detailed information on individual teachers including grade and subject taught, class size, years of experience, highest degree earned, and student population served. While individual student-teacher matches are not possible, students and teachers can be uniquely related to a grade on each campus. Each student is assigned the average class size and the distribution of teacher experience and turnover for teachers in regular classrooms for the appropriate grade, school, and year. 


\section{Empirical Results}

The basic investigation considers the overall impact of racial composition on student achievement, while extensions consider possible nonlinearities and other complications. It begins with simple models of the level and gain in achievement and expands the specifications by adding individual, school-by-grade, and district-by-year fixed effects, measured teacher and school characteristics, and the achievement level of peers. ${ }^{24}$ Throughout the analysis, the effects of racial composition and other peer characteristics are estimated separately for black, Hispanic and white students.

\section{Baseline Results}

Table 4 presents school racial composition coefficients from progressively richer specifications. While the simple model describing the level of achievement (column 1) indicates that achievement is lower in schools with higher proportions of black and Hispanic students, the dramatic change from looking at achievement growth (column 2) suggests that racial composition of the school is intertwined with various historical individual and school differences and that the simple aggregate achievement differences across schools cannot be readily interpreted.

The final four columns provide estimates from the models that incorporate first student and school-by-grade fixed effects in achievement growth (Column 3), then controls for measured teacher, school and other student characteristics (Column 4) and finally district-by-year fixed effects (Columns 5 and 6). Notice that columns 5 and 6 are based upon the same specification

24 A number of included variables, reported in the tables, are based on findings about specific factors affecting achievement growth (Rivkin, Hanushek, and Kain (2001), Hanushek, Kain, and Rivkin (2001)). At the individual level, all specifications include indicators for different types of school-to-school moves and an indicator for free lunch eligibility. Specifications that do not remove fixed effects contain dummy variables for the race, gender and ethnicity of each child, a full set of grade-by-year indicators, and dummy variables for community type. Estimates involving measured teacher and school characteristics include the rate of school transfers by students; the proportion with zero years of experience; and class size (all calculated by grade and subject). Preliminary specifications also included a measure of teacher turnover that was found to have no significant effect, and its exclusion had virtually no impact on the other 
except that the specification for column 6 adds a measure of peer average achievement in order to learn more about the source of any racial composition effect.

The basic fixed effect results suggest that a higher proportion of black schoolmates significantly reduces the achievement of black students. However, the inclusion of controls for teacher characteristics, student turnover and class size reduces the estimated effect of percent black by roughly one-third. It appears that the fixed effect estimates in models that lack these time varying variables confound the effect of school racial composition with that of inferior school characteristics (measured by class size, teacher experience and school turnover) that are correlated with racial composition across Texas schools in a complicated way. In contrast, the inclusion of district by-year-fixed effects that capture changes in leadership, curriculum, student and teacher assignment policies, or other factors that may be linked with changes in student racial composition has virtually no effect on the estimates of racial composition (column 5). This result provides strong evidence that the results are not being driven by an unobserved change in school quality that leads to changes in racial composition.

The estimates in the final column are conditional on average peer ability. The inclusion of average peer ability (average achievement of classmates measured in the third grade) barely changes the estimated effect of racial composition for black students, indicating that peer achievement differences do not drive the relationship between achievement and proportion black. $^{25}$

The magnitude of the proportion black coefficient for blacks of -0.25 suggests that a 10 percentage point reduction in percentage black would raise annual achievement growth by 0.025 standard deviations. These estimated effects apply to the growth of annual achievement and thus accumulate over grades. Our estimation, which applies to grades 5-7, does not provide

coefficients. Because some prior work suggests that class size and experience effects are larger for lower income students, these variable effects are permitted to differ for blacks and Hispanics. 
information on the effects of racial composition for earlier or later years of schooling, though the simple correlations in Table 1 suggest a smaller role for racial composition prior to fifth grade. Nonetheless, as we discuss below, the coefficient magnitude implies a substantial role for school racial composition in the determination of the racial achievement gap, even if the effects are not extrapolated to other grades.

The character of results for white and Hispanic students differs from those for blacks. First, the estimated effect of proportion black on the achievement of Hispanics and whites is much smaller (slightly over half as large) and not statistically significant at any conventional level in the full fixed effect specification. ${ }^{26}$ Moreover, the differences by race/ethnicity also provide evidence against the notion that unobserved differences in teacher or school quality account for all of the racial composition effect, for if that were the case the effect should be quite similar for all demographic groups. ${ }^{27}$

\section{Differences by $3^{\text {rd }}$ Grade Achievement Quartile}

One important question is whether the school racial composition effect varies along the achievement distribution. In particular, a variety of researchers, commentators, and community leaders emphasize that some blacks discourage others from excelling academically. ${ }^{28}$

Alternatively, others worry that teachers tend to lower expectations for black students as the

\footnotetext{
25 A further refinement that calculated two separate peer achievement variables, one based on own race/ethnic schoolmates and one based on remaining schoolmates yielded no significant changes in the results.

${ }^{26}$ As shown at the bottom of the table, the hypothesis that the effects for Blacks equals that for Whites or Hispanics is rejected at the 5 percent significance level ( $\mathrm{p}$ value of 0.02 and 0.04 , respectively, in the full model estimates).

${ }^{27}$ While we think the estimated racial composition effects are best interpreted as peer effects, the estimated impact of racial composition on whites and Hispanics could be used to establish a strong lower bound on the pure impact of black concentration in the schools. An extreme interpretation would be that whites and Hispanics are subject to no peer effects and that the estimated impact for them is simply lowered school quality that accompanies higher concentrations of blacks. In that case, the lower bound of the peer effect for blacks is half that calculated - still, as demonstrated below, a very substantial effect.

${ }^{28}$ This thesis has been very controversial with evidence on both sides. See, for example, Fordham and Ogbu (1986), Cook and Ludwig (1997), Steele and Aronson (1998), Ferguson (1998), and McWhorter (2000).
} 
proportion of students who are black rises. Each of these explanations would tend to produce a stronger relationship between achievement and proportion black for blacks at the higher end of the initial achievement distribution.

To examine the possibility that racial composition effects are larger for students with higher initial achievement, we interacted percent Black with indicators for a student's position in the overall achievement distribution. Specifically, we divide students into achievement quartiles on the basis of their third grade mathematics test score. This produces four percent black effects each for blacks, Hispanics and whites. The specifications displayed include time varying teacher, school, and other student characteristics and student, school-by-grade, and district-by-year fixed effects.

The results in Table 5 support the view that higher achieving blacks are much more sensitive to school racial composition: the coefficients increase monotonically along the initial achievement distribution and are only significant at the five percent level for the top two quartiles. The hypothesis that the effect of percent black is equal across the achievement distribution is rejected at the one percent level for blacks but not at any conventional level for whites (see the note to Table 5). Again the inclusion of peer average ability does not alter the link between achievement and proportion black, indicating that peer achievement differences do not drive the relationship. In addition, the estimated effects for whites and Hispanics (not shown) remain uniformly smaller and less significant than those for blacks, indicating that a higher proportion black does not appear to affect all higher achieving students similarly via curriculum decisions or other paths common to all students in the school. Rather the deleterious effects appear again to be much stronger for blacks than for Hispanics or whites.

The results in Table 5 paint a more complex picture of the link between achievement and racial composition. It appears that the upper end of the black achievement distribution is squeezed toward the median. This likely reduces black rates of college attendance, graduation, and employment in highly skilled and rewarding occupations. On the other hand, school racial 
composition appears to have a far smaller impact on blacks at the lower end of the achievement distribution in grades five through seven.

A final refinement of the interaction of racial composition and student ability is a more detailed consideration of the distributional aspects. Specifically, is the essential element where a black student falls in the overall ability distribution (absolute achievement) or where the student falls in the school distribution (skill relative to schoolmates)? Table 6 provides clear evidence on this by dividing students simultaneously in terms of the overall achievement distribution and the school distribution. For blacks, the estimated impact continues to rise along with the position in the overall achievement distribution, but within each third of the overall distribution there is little or no evidence of a systematic ordering by position in the school distribution. ${ }^{29}$ Moreover, separate estimates by position in the school achievement distribution alone (not shown) reveal no systematic ordering for blacks.

\section{Patterns of Racial Composition}

The prior analysis concentrates on the overall effects of racial composition across all of Texas. As described, however, the State of Texas is a composite of highly different communities with different histories and different development patterns. While many of the larger districts are still operating under court supervised desegregation plans that emanated from the days of de jure school segregation, no consistent data across Texas districts are available on even the existence of such legal plans let alone their nature. Nor is systematic information available on the community reactions to any court ordered or voluntary integration of schools, whether current or past.

Nonetheless, because some of the early investigations of court ordered desegregation suggested that the dynamics of integration within communities are important, we attempted an exploratory

\footnotetext{
${ }^{29}$ Note that students are divided into thirds of the distribution in order to have reasonable numbers of black students within each state-school cell. Still, some of the cells (e.g., top third of the state distribution and bottom third of the school distribution) are essentially empty, and these empty cells account for virtually all of the variation in point estimates within the cells of the statewide distribution.
} 
investigations of how varying paths of racial composition affects its impact on achievement. Employing the sample of 62 districts surveyed consistently over time by the Office of Civil Rights, we identified districts on the basis of changes in black exposure to white students (by school) between 1968 and 1992: increase exposure of 10 percent or more (27 districts), decreased exposure of 10 percent or more (15 districts), and the remainder (20 districts). Estimation of the basic achievement models but allowing the effects of racial composition to vary across the three subsets of districts yields no systematic patterns (not shown). The reduced samples yield much less precise estimates, and the point estimates indicate no obvious pattern.

Districts in Texas also vary dramatically in terms of the levels of racial exposure. As shown in Figure 1, there are a number of districts with few minority students, while other districts have very high levels of minority concentration. The possibility that the effect of percent black rises or falls as percent black increases led us to investigate the presence of such nonlinearities. However, after looking at up to quartic relationships in racial composition, we found no systematic effects above the linear estimates presented above. In perhaps the most persuasive analysis, we divided schools into those with 0-33, 34-66, and 67-100 percent black and considered differential effects of racial composition. The estimates, while imprecise particularly in the bottom range, show the same basic effects, and coefficient equality could not be rejected at standard levels.

Third, the earlier description in Table 1 suggested increasing impact by grade, with impact perhaps centered on middle school grades. We estimated the complete model with grade specific effects, but the analysis revealed no systematic pattern.

\section{Conclusions and Implications}

The difficulties of isolating school and peer group effects have been well documented. The role of peers, particularly in the context of racial integration, can be complex. By using a 
very large, matched panel data set from the state of Texas, we overcome many of the myriad methodological problems that impede the estimation of these effects.

The pattern of estimates supports the view that school proportion black has a negative effect on mathematics achievement growth for blacks that is concentrated in the upper half of the ability distribution. These racial composition effects for high ability blacks appear to be much stronger than those for whites, Hispanics, or low ability blacks. What is particularly important is that this effect does not appear to be driven by school quality differences, achievement differences of classmates, or even the specific distribution of ability within the school (as opposed to across the entire state distribution). While any interpretation would be speculative, the results are consistent with the views that blacks impose peer pressure on other blacks not to achieve and that a higher proportion black may lead teachers to reduce their expectations for all blacks.

The magnitude of the effects is significant. As show in Appendix Table A2, the typical black student (regardless of achievement quartile) has 30 percent greater black classmates than the typical white and has 25 percent more black classmates than would be obtained with a completely even distribution of blacks across the state. From our overall estimate of the impact of racial composition on black performance (Table 4), equalizing the black distribution throughout the entire state for just grades 5-7 (our observation period) would be consistent with an increase in black seventh grade achievement of 0.19 standard deviations. ${ }^{30}$ This amounts to slightly more than one-quarter of the seventh grade achievement gap between blacks and whites.

Of course the fact that the estimated adverse impact of racial composition increases in magnitude with the student's own achievement level indicates that the negative effects of black concentration on the racial achievement gap are disproportionately borne by blacks with higher academic achievement in the early grades. Blacks in the different quartiles of the ability distribution face essentially the same distribution of school racial composition in Texas; e.g., 
blacks in the bottom quartile in terms of third grade math achievement averaged 39 percent black classmates, while those in the top quartile averaged 43 percent (Appendix Table A2). Twentynine percent of black students fall in the top half of the third grade state math distribution (Appendix Table A1). By the estimates from Table 4, they suffer forty-two percent of the aggregate loss from the uneven racial distribution.

Note, moreover, that these are estimates of the pure racial composition effect. ${ }^{31}$ They say nothing about whether the school quality faced by the typical black is above or below average. Within this study, for example, the inclusion of time varying school characteristics reduces the estimated "pure impact" of racial composition, indicating that school quality tends to go down with increased black concentration. Differences in quality between schools in urban centers and suburban areas also support this general concern. ${ }^{32}$

The policy implications of these findings are, nonetheless, unclear, because of both the imbalance in the distribution of students across jurisdictions and the possibility that expanded exposure to nonblacks following additional desegregation activity could have a much different effect on achievement than that estimated from the current distribution of students among schools. The Brown decision and subsequent refinements in the case law with additional cases sharply restrict the circumstances in which interdistrict remedies are permissible Armor (1995). Thus, the room for direct school policy action to alter the overall racial composition of schools is currently very limited. One possible approach might be to develop special academic schools within districts (such as magnets) that might ameliorate the negative effects of composition on

\footnotetext{
${ }^{30}$ Equalizing the distribution of black students would reduce the average percentage of black classmates from 40 percent to the state percentage of blacks, 15 percent. If the impact in Table $3(-0.25)$ is accumulated for the three grades, the result would be a 0.19 standard deviation improvement in scores. 31 As noted in footnote 27, a limiting assumption is that the white and Hispanic estimates identify unmeasured school quality that is correlated with proportion black in the school, in which case the remaining elements of quality would be average differences by race and ethnic group.

32 Our prior investigation of Tiebout choice of schools found that, after correcting for individual selection effects, blacks in Texas on average attend poorer schools and face much more disruption in their schools from student mobility (Hanushek, Kain, and Rivkin (2001)). While not considering racial composition explicitly, schools with higher concentrations of blacks are located most frequently in the urban centers of Texas where schools on average are lower quality.
} 
higher ability black students. Nonetheless, while such policies have been pursued in a number of court-managed desegregation plans, little evidence on their effectiveness is known, and they remain limited by district boundaries.

An alternative supported by a range of prior investigations would emphasize a change in focus to housing policy. Over three decades ago, Kain and Persky (1969) suggested that: "De facto school segregation is another widely recognized limitation of Negro opportunities resulting from housing market segregation. A large body of evidence indicates that students in ghetto schools receive an education that is much inferior to that offered elsewhere." This led them to argue for more aggressive policies promoting housing desegregation as opposed to expensive compensatory strategies that left ghettos unaffected. Empirical analysis of segregation differences across metropolitan areas by Cutler and Glaeser (1997) finds direct impacts on educational attainment and other outcomes. More recently, the outcomes of the Gautreaux Program (Rosenbaum (1995)) and the Moving to Opportunity experiments (Katz, Kling, and Liebman (2001), Ludwig, Duncan, and Hirschfield (2001)) have reinforced the possibility of favorable outcomes from housing dispersal programs. Policies that support the continued suburbanization of black Americans and the slow, but steady decline in black-white segregation that has marked the last two decades (Cutler, Glaeser, and Vigdor (1999)) would, by the results of this paper, support improved schooling outcomes - particularly for higher achieving black students. 


\section{Table 1. Simple Correlation Coefficients Between School Average Mathematics Score and Percentage of Schoolmates Who Are Black for Grades Four through Seven, By Ethnicity}

\begin{tabular}{lcccc} 
& \multicolumn{4}{c}{ Grade } \\
\cline { 2 - 5 } Blacks & 4 & 5 & 6 & 7 \\
\cline { 2 - 5 } Hispanics & -0.03 & -0.05 & -0.13 & -0.28 \\
Whites & 0.00 & -0.01 & -0.02 & -0.03 \\
& -0.05 & -0.05 & -0.07 & -0.06
\end{tabular}

Note: The underlying data from which the correlations are derived refer to all public schools in Texas with performance measured by the Texas Assessment of Academic Skills; see data description and text. 


\section{Table 2. Racial Composition of Texas Schools, 1968-98}

$\begin{array}{lrrrrr} & 1968^{\mathrm{a}} & 1980^{\mathrm{a}} & 1992^{\mathrm{a}} & 1992^{\mathrm{b}} & 1998^{\mathrm{b}} \\ \text { Percentage Black } & 16.1 & 14.4 & 15.2 & 14.3 & 14.4 \\ \text { Percentage Hispanic } & 19.3 & 30.4 & 29.7 & 34.5 & 37.9 \\ \text { Percentage White } & 64.3 & 54.1 & 52.7 & 48.8 & 45.0 \\ & & & & & 3,897,641 \\ \text { Enrollment } & 2,662,720 & 2,846,106 & 3,504,860 & 3,464,371 & \end{array}$

Notes: a. Weighted calculations using data from the Bi-Annual Survey of Public Schools of Office of Civil Rights (OCR) of the Department of Education for 65 sampled districts from Texas that appear in the 1968, 1980, and 1992 surveys.

b. Calculations using data from PEIMS (Public Education Information Management System) of the State of Texas.

\section{Table 3. Black/White Exposure and Dissimilarity Indexes, 1968 to 1998}

School Year

Exposure Index (\%)

Dissimilarity Index (\%)

Across schools

Across districts $1968^{\mathrm{a}}$

24.4

74.2

44.3 $1980^{\mathrm{a}}$

35.2

61.1

54.7 $1992^{\mathrm{a}}$

33.0

34.6

57.5

51.7

59.6

53.3 $1998^{b}$

30.9
59.1

52.3

Notes: a. Weighted calculations using data from the Bi-Annual Survey of Public Schools of Office of Civil Rights (OCR) of the Department of Education.

b. Calculations using data from PEIMS (Public Education Information Management System) of the State of Texas.

c. Percentage white schoolmates for the average black student.

d. Percentage of black students who would have to change schools (districts) to have a uniform distribution of black students across schools (districts). 


\section{Table 4. Estimated Effects of Peer Racial Composition and Average Achievement on Mathematics Achievement Level and Achievement \\ Gains (absolute value of Huber -White adjusted t-statistics in parentheses)}

\begin{tabular}{|c|c|c|c|c|c|c|}
\hline & \multirow{3}{*}{$\begin{array}{c}\text { Level } \\
\left(\mathrm{A}_{\mathrm{i}}\right)\end{array}$} & \multirow{2}{*}{\multicolumn{5}{|c|}{ Achievement growth $\left(\Delta \mathrm{A}_{\mathrm{i}}\right)$}} \\
\hline & & & & & & \\
\hline & & \multicolumn{2}{|c|}{$\begin{array}{l}\text { Without measured teacher } \\
\text { and school characteristics }\end{array}$} & \multicolumn{3}{|c|}{$\begin{array}{l}\text { With measured teacher and school } \\
\text { characteristics }^{\mathrm{a}}\end{array}$} \\
\hline & & \multicolumn{3}{|c|}{$\begin{array}{l}\text { Student and school-by- } \\
\text { grade fixed effects }\end{array}$} & \multicolumn{2}{|c|}{$\begin{array}{c}\text { Student, school-by-grade, } \\
\text { and district-by-year fixed } \\
\text { effects }\end{array}$} \\
\hline Proportion black & $\begin{array}{c}-0.22 \\
(5.31)\end{array}$ & $\begin{array}{l}-0.05 \\
(2.14)\end{array}$ & $\begin{array}{l}-0.30 \\
(2.87)\end{array}$ & $\begin{array}{l}-0.21 \\
(2.01)\end{array}$ & $\begin{array}{l}-0.22 \\
(2.34)\end{array}$ & $\begin{array}{l}-0.25 \\
(2.51)\end{array}$ \\
\hline Proportion Hispanic & $\begin{array}{l}-0.12 \\
(2.73)\end{array}$ & $\begin{array}{l}-0.05 \\
(2.07)\end{array}$ & $\begin{array}{l}-0.04 \\
(0.42)\end{array}$ & $\begin{array}{c}0.03 \\
(0.33)\end{array}$ & $\begin{array}{c}0.06 \\
(0.77)\end{array}$ & $\begin{array}{c}0.04 \\
(0.51)\end{array}$ \\
\hline Average math score & & & & & & $\begin{array}{c}-0.03 \\
(1.15)\end{array}$ \\
\hline \multicolumn{7}{|l|}{ White students } \\
\hline Proportion black & $\begin{array}{l}-0.11 \\
(3.25)\end{array}$ & $\begin{array}{l}-0.01 \\
(0.59)\end{array}$ & $\begin{array}{l}-0.12 \\
(1.16)\end{array}$ & $\begin{array}{l}-0.13 \\
(1.28)\end{array}$ & $\begin{array}{l}-0.13 \\
(1.44)\end{array}$ & $\begin{array}{l}-0.14 \\
(1.47)\end{array}$ \\
\hline Proportion Hispanic & $\begin{array}{l}-0.03 \\
(1.68)\end{array}$ & $\begin{array}{c}0.02 \\
(1.85)\end{array}$ & $\begin{array}{c}0.06 \\
(0.76)\end{array}$ & $\begin{array}{c}0.03 \\
(0.41)\end{array}$ & $\begin{array}{c}0.08 \\
(1.19)\end{array}$ & $\begin{array}{c}0.08 \\
(1.16)\end{array}$ \\
\hline Average math score & & & & & & $\begin{array}{c}0.00 \\
(0.21)\end{array}$ \\
\hline \multicolumn{7}{|l|}{ Hispanic students } \\
\hline Proportion black & $\begin{array}{l}-0.20 \\
(4.19)\end{array}$ & $\begin{array}{l}-0.04 \\
(1.91)\end{array}$ & $\begin{array}{l}-0.22 \\
(1.99)\end{array}$ & $\begin{array}{l}-0.16 \\
(1.43)\end{array}$ & $\begin{array}{l}-0.13 \\
(1.32)\end{array}$ & $\begin{array}{l}-0.14 \\
(1.40)\end{array}$ \\
\hline Proportion Hispanic & $\begin{array}{l}-0.08 \\
(3.28)\end{array}$ & $\begin{array}{c}0.01 \\
(0.87)\end{array}$ & $\begin{array}{c}0.00 \\
(0.06)\end{array}$ & $\begin{array}{c}0.02 \\
(0.31)\end{array}$ & $\begin{array}{c}0.09 \\
(1.20)\end{array}$ & $\begin{array}{c}0.09 \\
(1.23)\end{array}$ \\
\hline Average math score & & & & & & $\begin{array}{c}0.00 \\
(0.21) \\
\end{array}$ \\
\hline $\begin{array}{l}\text { Test of black-white } \\
\text { equality for proportion } \\
\text { black effect }^{\mathrm{b}}\end{array}$ & & & & 0.07 & .04 & .02 \\
\hline $\begin{array}{l}\text { Test of black-Hispanic } \\
\text { equality for proportion } \\
\text { black effect }^{\mathrm{c}}\end{array}$ & & & & & .08 & .04 \\
\hline sample size & 378,512 & & & $1,013,749$ & & \\
\hline
\end{tabular}

Note: a. Models include teacher characteristics (experience categories) class size, and student turnover.

b. P-values from t-test for $\mathrm{H}_{\mathrm{o}}: \lambda_{\text {black }}=\lambda_{\text {white }} ; \mathrm{H}_{1}: \lambda_{\text {black }} \neq \lambda_{\text {white }}$.

c. P-values from t-test for $\mathrm{H}_{\mathrm{o}}: \lambda_{\text {black }}=\lambda_{\text {Hispanic }} ; \mathrm{H}_{1}: \lambda_{\text {black }} \neq \lambda_{\text {Hispanic }}$. 


\section{Table 5. Estimated Effects of Peer Racial Composition and Achievement on Mathematics Test Score Gains by Quartile of the}

Test Score Distribution (absolute value of Huber-White adjusted $t$ statistics in parentheses)

\begin{tabular}{lcccc} 
& $\begin{array}{c}\text { Bottom } \\
\text { Quartile }\end{array}$ & $\begin{array}{c}\text { Second } \\
\text { Quartile }\end{array}$ & $\begin{array}{c}\text { Third } \\
\text { Quartile }\end{array}$ & $\begin{array}{c}\text { Top } \\
\text { Quartile }\end{array}$ \\
\cline { 2 - 5 } $\begin{array}{l}\text { 1.Without peer achievement } \\
\text { Proportion black }\end{array}$ & & & & \\
2. With peer achievement & -0.17 & -0.20 & -0.29 & -0.38 \\
& & $(1.97)$ & $(2.85)$ & $(3.52)$ \\
Proportion black & -0.19 & -0.20 & -0.32 & -0.40 \\
Average math score & $(1.82)$ & $(1.99)$ & $(3.07)$ & $(3.58)$ \\
& -0.03 & 0.00 & -0.06 & -0.02 \\
White students & $(0.85)$ & $(0.06)$ & $(1.83)$ & $(0.56)$ \\
1.Without peer achievement & & & & \\
Proportion black & & & & \\
2. With peer achievement & $(0.94)$ & $(1.67)$ & $(1.06)$ & $(1.71)$ \\
Proportion black & & & & \\
Average math score & -0.10 & -0.16 & & \\
& $(0.40)$ & $(1.10)$ & $(0.49)$ & $(1.13)$ \\
& -0.02 & 0.00 & 0.02 & -0.02 \\
& $(0.95)$ & $(0.09)$ & $(1.43)$ & $(0.91)$
\end{tabular}

Note: Separate equations are estimated for models with and without peer achievement (third grade). All regressions include student, school-by-grade, and district-by-year fixed effects plus class size, teacher characteristics, and student turnover. F tests of the probability that the effects are equal across the achievement distribution have $p$ values of 0.01 for blacks and 0.31 for whites for fixed effect specifications with no control for peer achievement. 


\section{Table 6. Estimated Effects of Proportion Black Students by Position in Statewide and in School-wide Distribution of Ability}

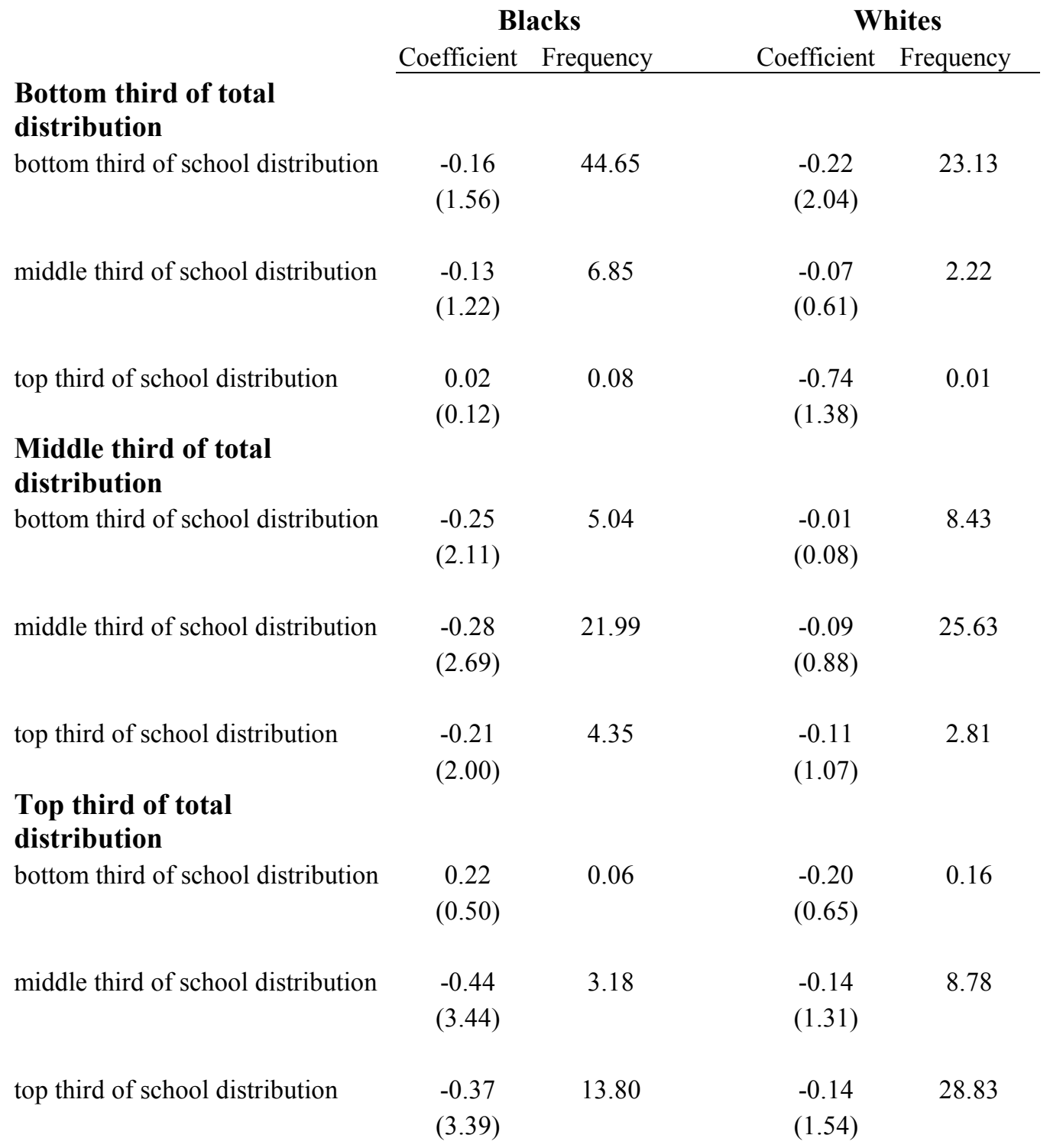

Note: All regressions include student, school-by-grade, and district-by-year fixed effects plus class size, teacher characteristics, and student turnover. 
Appendix Table A1. Achievement Distribution for Blacks and Whites by Quartile of State Math Test Score Distribution

\begin{tabular}{lccccc} 
& \multicolumn{5}{c}{ State Test Scores (Third grade) } \\
\cline { 2 - 6 } & $\begin{array}{c}\text { Bottom } \\
\text { Quartile }\end{array}$ & $\begin{array}{c}\text { Second } \\
\text { Quartile }\end{array}$ & $\begin{array}{c}\text { Third } \\
\text { Quartile }\end{array}$ & $\begin{array}{c}\text { Top } \\
\text { Quartile }\end{array}$ & All \\
\hline Placement in achievement distribution & & & & & \\
$\quad$ Black students & 41.4 & 30.0 & 19.1 & 9.5 & 100 \\
$\quad$ White students & 14.7 & 21.6 & 28.5 & 35.2 & 100 \\
& & & & & \\
\hline
\end{tabular}

Appendix Table A2. Percentage of Racial and Ethnic Classmates for Black and White Students by Quartile of State Math Test Score Distribution

\begin{tabular}{ccccc}
\multicolumn{5}{c}{ State Test Scores (Third grade) } \\
\hline Bottom & Second & Third & Top \\
Quartile & Quartile & Quartile & Quartile & All \\
\hline \multicolumn{5}{c}{} \\
& & & & \\
38.5 & 38.1 & 39.9 & 42.8 & 39.2 \\
9.4 & 9.3 & 9.2 & 9.3 & 9.3
\end{tabular}

Hispanic classmates for:

$\begin{array}{lllllc}\text { Black students } & 21.6 & 21.4 & 20.9 & 21.0 & 21.4 \\ \text { White students } & 19.3 & 18.4 & 17.6 & 17.3 & 18\end{array}$

Black classmates for:

Black students

White students

18.4

20.9

17.3 


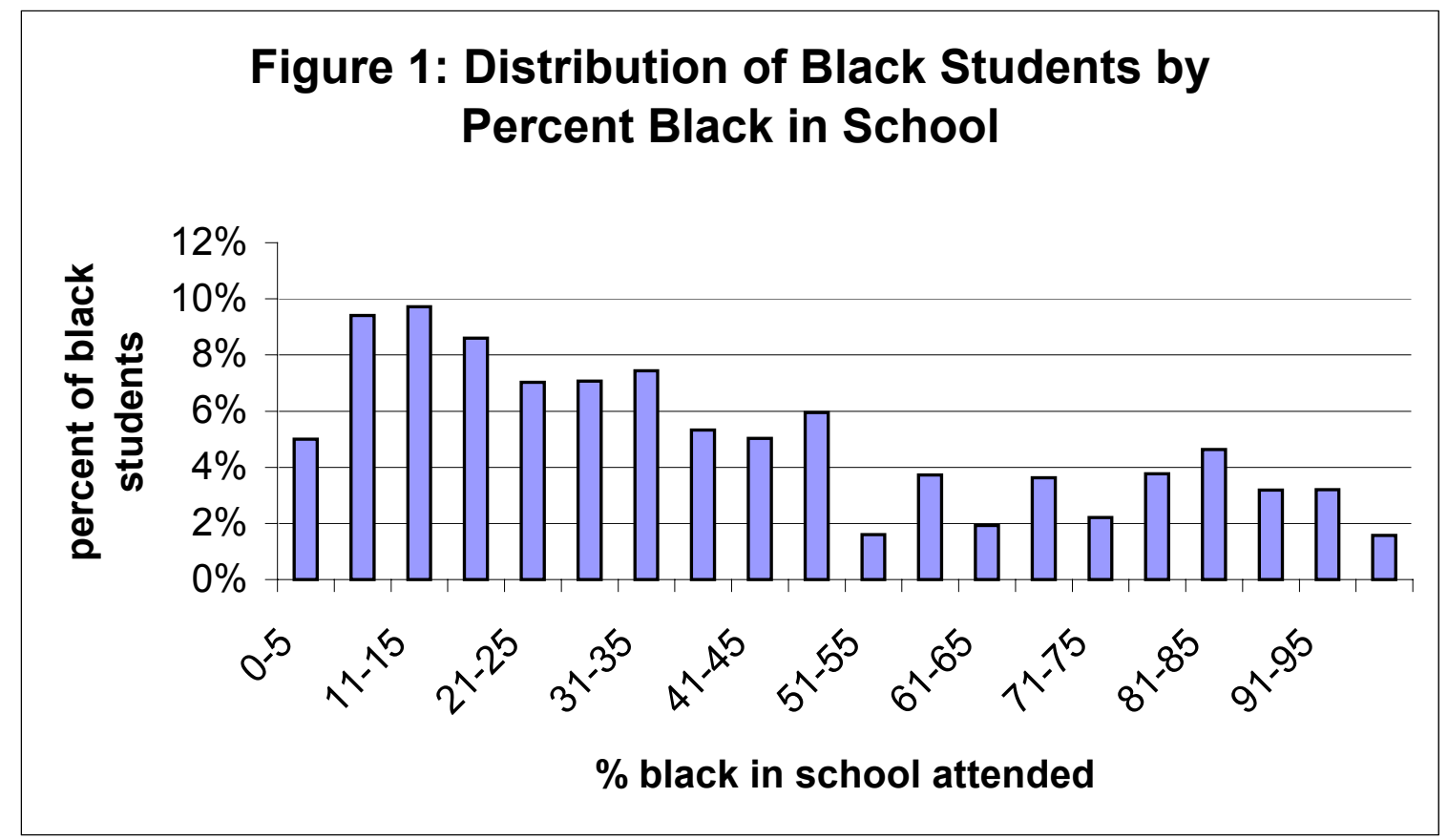




\section{References}

Armor, David J. 1972. "The evidence on busing." Public Interest 28(Summer):90-126.

1995. Forced justice: School desegregation and the law. New York: Oxford University Press.

Boozer, Michael A., Alan B. Krueger, and Shari Wolkon. 1992. "Race and school quality since Brown v. Board of Education." Brooking Papers: Microeconomics:269-338.

Brock, William A., and Steven N. Durlauf. forthcoming. "Interactions-based models." In Handbook of Econometrics.

Clark, Kenneth, and Mamie Clark. 1939. "The development of consciousness of self and the emergence of racial identity in Negro children." Journal of Social Psychology 10:591599 .

Clotfelter, Charles T. 1976. "School desegregation, "tipping," and private school enrollment." Journal of Human Resources 22,no.1 (Winter):29-50.

_ 2001. "Are white still fleeing? Racial patterns and enrollment shifts in urban public schools." Journal of Policy Analysis and Management 20,no.2 (Spring):199-221.

Clotfelter, Charles T., Helen F. Ladd, and Jacob L. Vigdor. 2002. "Who teaches whom? Race and the distribution of novice teachers." Paper presented at the annual meetings of the American Economic Association, Atlanta, Georgia (January).

Coleman, James S., Ernest Q. Campbell, Carol J. Hobson, James McPartland, Alexander M. Mood, Frederic D. Weinfeld, and Robert L. York. 1966. Equality of educational opportunity. Washington, D.C.: U.S. Government Printing Office.

Coleman, James S., Thomas Hoffer, and Sally Kilgore. 1982. High school achievement: public, Catholic and private schools compared. NY: Basic Books.

Coleman, James S., Sara D. Kelley, and John A. Moore. 1975. "Trends in school integration, 1968-73." Paper 722-03-01, Urban Institute

Cook, Michael D., and William N. Evans. 2000. "Families or schools? Explaining the convergence in white and black academic performance." Journal of Labor Economics 18,no.4 (October):729-754.

Cook, Philip J., and Jens Ludwig. 1997. "Weighing the "burden of 'acting white"': Are there race differences in attitudes toward education?" Journal of Policy Analysis and Management 16,no.2 (Spring):256-278. 
Cook, Thomas D. 1984. "What have black children gained academically from school desegregation? A review of the metaanalytic evidence." In School desegregation. Washington, DC: National Institute of Education.

Crain, Robert. 1970. "School integration and occupational achievement of Negroes." American Journal of Sociology 75,no.4, Part II (January):593-606.

Crain, Robert L., and Rita E. Mahard. 1978. "Desegregation and black achievement: A review of the research." Law and Contemporary Problems 42,no.3:17-53.

Cutler, David M., and Edward L. Glaeser. 1997. "Are ghettos good or bad?" Quarterly Journal of Economics 112,no.3 (August):827-872.

Cutler, David M., Edward L. Glaeser, and Jacob L. Vigdor. 1999. "The rise and decline of the American ghetto." Journal of Political Economy 107,no.3 (June):455-506.

Ferguson, Ronald. 1998. "Comment [on Cook and Ludwig]." In The black-white test score gap, edited by C. Jencks and M. Phillips. Washington, DC: Brookings Institution.

Fordham, Signithia, and John Ogbu. 1986. "Black students' school success: Coping with the burden of 'acting white'." The Urban Review 58:54-84.

Grogger, Jeffrey T. 1996. "Does school quality explain the recent black/white wage trend?" Journal of Labor Economics 14,no.2 (April):231-253.

Hanushek, Eric A. 1972. Education and race: an analysis of the educational production process. Cambridge, MA: Health-Lexington.

. 1979. "Conceptual and empirical issues in the estimation of educational production functions." Journal of Human Resources 14,no.3 (Summer):351-388.

—. 1986. "The economics of schooling: Production and efficiency in public schools." Journal of Economic Literature 24,no.3 (September):1141-1177.

_ 1997. "Assessing the effects of school resources on student performance: An update." Educational Evaluation and Policy Analysis 19,no.2 (Summer):141-164.

Hanushek, Eric A., John F. Kain, Jacob M. Markman, and Steven G. Rivkin. forthcoming. "Does peer ability affect student achievement?" Journal of Applied Econometrics.

Hanushek, Eric A., John F. Kain, and Steve G. Rivkin. 2001. "Disruption versus Tiebout improvement: The costs and benefits of switching schools." WP 8479, National Bureau of Economic Research (September).

— forthcoming. "Inferring program effects for specialized populations: Does special education raise achievement for students with disabilities?" Review of Economics and Statistics.

Hoxby, Caroline Minter. 2000. "Peer Effects in the Classroom: Learning from Gender and Race Variation." Working Paper No. 7867, National Bureau of Economic Research (August). 
Kain, John F., and Daniel M. O'Brien. 2000. "Black suburbanization in Texas metropolitan areas and its impact on student achievement." Working paper, Green Center for the Study of Science and Society, University of Texas at Dallas (March).

Kain, John F., and Joseph J. Persky. 1969. "Alternatives to the gilded ghetto." Public Interest 14.

Katz, Lawrence F., Jeffrey R. Kling, and Jeffrey B. Liebman. 2001. "Moving to Opportunity in Boston: Early results of a randomized mobility experiment." Quarterly Journal of Economics 116,no.2 (May):607-654.

Lazear, Edward P. 2001. "Educational production." Quarterly Journal of Economics 116,no.3 (August):777-803.

Ludwig, Jens, Greg J. Duncan, and Paul Hirschfield. 2001. "Urban poverty and juvenile crime: Evidence from a randomized housing-mobility experiment." Quarterly Journal of Economics 116,no.2 (May):655-679.

Manski, Charles F. 1993. "Identification of endogenous social effects: The reflection problem." Review of Economic Studies 60(July):531-542.

Massey, D., and N. Denton. 1993. American apartheid: Segregation and the making of the underclass. Cambridge, MA: Harvard University Press.

McWhorter, Jon H. 2000. Losing the race: Self-sabotage in black America. New York: The Free Press.

Moffitt, Robert A. 2001. "Policy interventions, low-level equilibria, and social interactions." In Social dynamics, edited by S. Durlauf and H. P. Young. Cambridge, MA: MIT Press.

Rivkin, Steven G. 1994. "Residential segregation and school integration." Sociology of Education 67,no.4 (October):279-292.

- 2000. "School desegregation, academic attainment, and earnings." Journal of Human Resources 35,no.2 (Spring):333-346.

Rivkin, Steven G., Eric A. Hanushek, and John F. Kain. 2001. "Teachers, schools, and academic achievement." Working Paper No. 6691, National Bureau of Economic Research (revised)

Rosenbaum, James E. 1995. "Changing the geography of opportunity by expanding residential choice: Lessons from the Gautreaux Program." Housing Policy Debate 6,no.1:231-269.

Schofield, Janet Ward. 1995. "Review of research on school desegregation's impact on elementary and secondary school students." In Handbook of research on multicultural education, edited by J. A. Banks and C. A. M. Banks. New York: Macmillan Publishing.

Steele, Claude M., and Joshua Aronson. 1998. "Stereotype threat and the test performance of academically successful African Americans." In The black-white test score gap, edited by C. Jencks and M. Phillips. Washington, DC: Brookings Institution. 
Tiebout, Charles M. 1956. "A pure theory of local expenditures." Journal of Political Economy 64(October):416-424.

U.S. Commission on Civil Rights. 1967. Racial isolation in the public schools. Washington, DC: Government Printing Office.

Welch, Finis, and Audrey Light. 1987. New evidence on school desegregation. Washington, D.C.: U. S. Commission on Civil Rights. 